\title{
Regarding "MR Imaging of the Cervical Spine in Nonaccidental Trauma: A Tertiary Institution Experience"
}

W e would like to thank Jacob et al for raising an important, relevant issue in their article entitled "MR Imaging of the Cervical Spine in Nonaccidental Trauma: A Tertiary Institution Experience." ${ }^{1}$ They reported a relatively high incidence (69\%) of cervical spine injury (CSI) in nonaccidental trauma compared with the literature and concluded that positive findings on MR imaging may affect management and, therefore, recommending routine use of MRI in suspected nonaccidental trauma.

However, it is not clear how the authors reached that conclusion. They have not specified how the MR imaging findings impacted management in their study population. Are the authors advocating the use of MR imaging for the diagnosis of nonaccidental trauma, distinguishing accidental from nonaccidental trauma, or management of patients with nonaccidental trauma? Although ligamentous signal on MR imaging was seen in $67 \%$ of patients, this was mostly confined to the interspinous and nuchal ligaments. From the description of findings in the study population, would the authors agree that none of the patients had unstable injury? Although this was a retrospective study, would prospective knowledge of these findings change management and in what circumstances?

Previous studies have shown that MR imaging signs of cervical spine injury did not show a statistical relationship with outcome or help discriminate accidental and abusive head trauma. ${ }^{2} \mathrm{Al}-$ though cervical spine injury was seen on MR imaging in 36\% of patients, none required surgical intervention in the study by Kadom et al. ${ }^{2}$

Despite the higher soft-tissue contrast resolution, MR imaging has not been shown to detect unstable CSIs in patients with CT with negative findings, either in the pediatric or adult population. ${ }^{3}$ Choudhary et $\mathrm{al}^{4}$ found a higher incidence of ligamentous injury in nonaccidental trauma compared with accidental injuries, but the pattern of injuries was similar. ${ }^{4}$ Jacob et $\mathrm{al}^{1}$ used that study as evidence that MR imaging findings actually reflect pathology because the cohort of patients without trauma did not show similar MR imaging abnormalities. However, there was no blinding for the healthy cohort in the study by Choudhary et al. The few studies that have correlated MR imaging findings of lig- amentous signal abnormalities with intraoperative or postmortem findings have found a poor correlation. ${ }^{5}$ In a comparison of 4 modalities to assess cervical spine instability in pediatric trauma, Brockmeyer et $\mathrm{al}^{6}$ found MR imaging to be sensitive but not specific $(74 \%)$. Because of the low specificity, the authors recommended that MR imaging be performed only in patients with neurologic deficits or to follow up a screening study with positive findings.

Performance of MR imaging is not without challenges, risks, and costs in this study population. As per the authors, only $43 \%$ of patients in this study had superior quality imaging. The recommendation by the authors of routinely including cervical spine MR imaging as part of the armamentarium of tests while working up a child with nonaccidental trauma probably needs answers to our questions and more evidence.

\section{REFERENCES}

1. Jacob R, Cox M, Koral K, et al. MR imaging of the cervical spine in nonaccidental trauma: a tertiary institution experience. AJNR Am J Neuroradiol 2016 May 26. [Epub ahead of print] CrossRef Medline

2. Kadom N, Khademian Z, Vezina G, et al. Usefulness of MRI detection of cervical spine and brain injuries in the evaluation of abusive head trauma. Pediatr Radiol 2014;44:839-48 CrossRef Medline

3. Malhotra A, Wu X, Kalra VB, et al. Utility of MRI for cervical spine clearance after blunt traumatic injury: a meta-analysis. Eur Radiol 2016 Jun 22. [Epub ahead of print] Medline

4. Choudhary AK, Ishak R, Zacharia TT, et al. Imaging of spinal injury in abusive head trauma: a retrospective study. Pediatr Radiol 2014;44: 1130-40 CrossRef Medline

5. Goradia D, Linnau KF, Cohen WA, et al. Correlation of MR imaging findings with intraoperative findings after cervical spine trauma. AJNR Am J Neuroradiol 2007;28:209-15 Medline

6. Brockmeyer DL, Ragel BT, Kestle JR. The pediatric cervical spine instability study: a pilot study assessing the prognostic value of four imaging modalities in clearing the cervical spine for children with severe traumatic injuries. Childs Nerv Syst 2012;28:699-705 CrossRef Medline

(1) X. Wu

(1)D. Durand

(ID) Bao

(D) Aalhotra

Department of Radiology and Biomedical Imaging Yale School of Medicine New Haven, Connecticut 